\title{
AN INVESTIGATION OF RETURNS TO INSIDER TRANSACTIONS: EVIDENCE FROM THE ISTANBUL STOCK EXCHANGE
}

\author{
ÇAĞDAŞ TAHAOĞLU** \\ Middle East Technical University
}

\author{
Z. NURAY GÜNER ${ }^{* * *}$ \\ Middle East Technical University
}

\begin{abstract}
In this paper, the return performance of insiders of companies listed on the Istanbul Stock Exchange (ISE) from their open market transactions and that of uninformed investors (outsiders) following insider transactions announced to the public are examined by using a portfolio approach. It is found that, depending on the affiliation of the insider with the company, abnormal returns from their sale transactions last over longer periods than their purchase transactions. Furthermore, outsiders can also earn abnormal returns by mimicking sales of affiliated shareholders of a company. Findings of this study imply that the ISE is neither Semi Strong nor Strong Form Efficient.
\end{abstract}

Keywords: insider trading, emerging market, Istanbul Stock Exchange, ISE, market efficiency.

\section{IÇERIDEN ÖĞRENEN ISSLEMLERINDDEN ELDE EDILLEN GETIRILERIN INCELENMESİ: ISTANBUL MENKUL KIYMETLER BORSASINDAN BULGULAR}

\begin{abstract}
ÖZET
Bu makalede, İstanbul Menkul Kıymetler Borsası (IMKB)'nda işlem gören şirketlerdeki içeriden ögrenenlerin serbest piyasa işlemlerinin getiri performansl ve içeriden öğrenenlerin bu işlemlerini takip eden diğer yatırımcıların olası getiri performansı portföy yaklaşımı kullanılarak incelenmistir. Şirketteki pozisyonlarına bağlı olarak, içeriden öğrenenlerin satım işlemlerinden, alım işlemlerine kıyasla, daha uzun sürelerde olağan dışı pozitif getiriler elde ettikleri bulunmuştur. Ayrıca dĭ̆er yatırımcılar, şirket ile ilişkili kişilerin veya firmaların satımlarını taklit ederek olağan dışı getiri elde edebilmektedirler. Bu makalenin bulguları, IMKB'nin güçlü veya yarı güçlü formda etkin olmadı ̆̆ına işaret etmektedir.
\end{abstract}

Anahtar kelimeler: içeriden öğrenen ticareti, gelişmekte olan piyasa, İstanbul Menkul Kıymetler Borsası, IMMKB, piyasa etkinliği.

* This article is part of Çağdaş Tahaoğlu's master thesis written under the supervision of Professor Z. Nuray Güner.

** Çağdaş Tahaoğlu is a PhD student at Middle East Technical University, Dumlupınar Bulvarı, 06800, Ankara, Turkey. E-mail: cagdastaha@gmail.com

*** Z. Nuray Güner is a Professor in the Department of Business Administration at Middle East Technical University, Dumlupınar Bulvarı, 06800, Ankara, Turkey. E-mail: nguner@ba.metu.edu.tr 
Insider trading has always been an attractive subject for the academia and public. This interest stems from the insiders' monopolistic access to material information which is not yet shared with other market participants (non-public information) about their companies. Because of their monopolistic access to extensive information (e.g. current inventory levels, dates of new product launches, current market share, etc.) related to the future prospects of their companies, insiders are the most probable group to detect misvaluations in current prices of their company shares and generate above average (abnormal) returns consistently from investing in the mispriced shares of their company.

Until recently, studies analyzing the profitability of insider trades are concentrated mostly on the US exchanges and developed markets. However, it would be interesting to see whether profit opportunities exist for insiders in an emerging market which may not have the efficiency level of developed markets. This paper aims to provide evidence on the return performance of the insiders and uninformed investors (outsiders) mimicking transactions of insiders in an emerging market, namely the Istanbul Stock Exchange (ISE). In this market, investors who are legally identified as insiders are obligated to inform the ISE of their trades until 9:00 am of the workday following their transaction. Their trades are announced to the public by the closing of trading on the day of their disclosures to the ISE. Therefore, there is not much of a delay in the announcement of insider trades to the public in this market. Delay in announcement of insider trades to the public is usually claimed to be the reason behind not finding any profit opportunities for outsiders mimicking insider trades (Bettis et al., 1997). Due to immediate announcement of insider trades to the public, outsiders might have higher profit opportunities in the ISE compared to other markets. Furthermore, this study provides evidence on profitability of insider trades from a stock market where insiders of some companies trade quite actively. To avoid introducing biases due to the high possibility of overlapping event and/or estimation periods, a portfolio approach that is similar to a calendar time portfolio approach, rather than the standard event study methodology, is implemented to estimate abnormal returns earned by insiders and outsiders following insider transactions. ${ }^{(1)}$

Return performance of insiders and outsiders mimicking the trades of insiders are evaluated by constructing rolling value weighted net purchase and net sale portfolios from the daily insider trading data. As opposed to a similar study done by Jeng et al. (2003) for the US markets, we construct our portfolios on a net basis to reflect trade positions of insiders as a group at all points in time. These portfolios are constructed to estimate a proxy to returns earned by insiders from their net transactions. Similarly, outsider portfolios are built to assess whether uninformed investors can earn abnormal returns by mimicking transactions of insiders on the day following the public disclosure of insider trades. Abnormal returns to these portfolios are examined over different holding periods (5-, 10-, 21-, 42- and 63-day holding periods) due to lack of regulations in the Turkish stock market restricting insiders from exploiting short-term profit opportunities at any time. Furthermore, performance of subportfolios based on affiliation of insiders with the company, which is shown to have an impact on the profits to insiders and outsiders following insider transactions by earlier studies (Baesel and Stein, 1979; Jaffe, 1974; Seyhun, 1986, 1998), is examined in this study.

The analyses conducted in this study indicate that insiders, ${ }^{(2)}$ as a group, earn risk adjusted abnormal returns from their net purchases and sales only over short horizons. This finding might be due to analyzing transactions of Non-Affiliated (i.e., institutional investors and shareholders who do not hold administrative or operational positions in the company) and Affiliated (i.e., Directors, Officers and Affiliated companies) investors together since these parties are all considered as insiders. When 
transactions of Non-Affiliated shareholders are examined separately, it is shown that they earn positive abnormal returns only from their net sales over the 5-day holding period. However, Affiliated shareholders earn positive abnormal returns, when they are net sellers of their company shares regardless of the holding period analyzed. On the other hand, they earn abnormal returns from their net purchases only over the previous 5 days.

Existence of profit opportunities for outsiders from following the disclosure of insider transactions is also examined. Risk adjusted return estimates for net purchase and sale portfolios indicate that uninformed investors, in general, cannot earn abnormal returns by employing an investment strategy founded on mimicking all insider transactions disclosed to the public. Furthermore, it is shown that outsiders cannot earn positive abnormal returns by purchasing stocks that are net bought by insiders even when implementing strategies based on affiliation of insiders with the company. However, uninformed investors can avoid below (earn above) market risk adjusted returns by not purchasing (short-selling) stocks that are net sold by Affiliated shareholders over all holding periods analyzed in this paper.

Findings of this paper are in line with earlier studies in the literature that point out the difference between returns to insiders based on their affiliation with the underlying company. Secondly, since other investors can also benefit from following disclosures of Affiliated shareholders, share prices do not seem to adjust to information released by transactions of insiders quickly enough. This can be taken as evidence against the Semi Strong or the Strong Form Efficiency of the Istanbul Stock Exchange.

In the next section, related literature on the subject is reviewed. The following section describes the regulatory environment and the data. Later, the methodology that is used in order to assess abnormal returns for insiders and outsiders from their transactions is explained. This is followed by a discussion of empirical results. The final section presents the conclusions drawn from the empirical analysis.

\section{RELATED LITERATURE}

In most of the countries with a stock exchange, ${ }^{(3)}$ existing insider trading laws require insiders to disclose their transactions to the public. Besides from the public's interests on the disclosures of insider trades as an input to their investment decision making process, empirical research on regulatory filings of insider trades mainly stems from interest of academia to test the Efficient Market Hypothesis (EMH) formulated by Fama (1970).

Empirical research on stock markets in the United States (US), including Jaffe (1974), Finnerty (1976) and Seyhun (1986, 1998), Rozeff and Zaman (1988), and Lin and Howe (1990), generally finds that insiders, on average, earn above market returns from their transactions and reject the strong form efficiency of the markets. On the other hand, the semi-strong form efficiency of the US stock markets is still debatable based on studies that investigate availability of profitable trading opportunities for uninformed investors from following insider transaction disclosures. Studies done by Seyhun (1986), Rozeff and Zaman (1988), and Lin and Howe (1990) show that outsiders do not earn abnormal returns when transaction costs are taken into account. Later, Bettis et al. (1997) argue that the unprofitability of outsiders following the trades of insiders documented by Seyhun (1986), and Rozeff and Zaman (1988) is due to delays in dissemination of insider-trading data to investors during the periods analyzed in 
those studies. They use CDA/Investnet's Insider Trading Monitor rather than Securities and Exchange Commission's (SEC) monthly publication, Official Summary of Security Transactions and Holdings, to identify the date of public dissemination of transactions. Their results show that outsiders can earn abnormal returns by mimicking the transactions of top executives involving over 10,000 shares.

Studies conducted on international developed markets mostly confirm findings of the studies done on the US stock markets that there exist abnormal returns following insider transactions; hence, stock markets are not strong form efficient. Some examples of other developed countries in which the profitability of insider trading analyzed are: Canada (Baesel and Stein, 1979), United Kingdom (Friederich et al., 2002; Pope et al., 1990), Spain (Del Brio et al., 2002), Italy (Bajo and Petracci, 2006) and Germany (Betzer and Theissen, 2009).

Most of the studies cited above equally weight each insider transaction, and then estimate abnormal returns to insiders either by using an event study methodology or a portfolio approach. Only two papers try to estimate value weighted returns earned by insiders. The first paper is the one by Eckbo and Smith (1998), which estimates insiders' performance on the Oslo Stock Exchange by aggregating insider holdings into a value weighted portfolio. Their results show that insiders do not earn abnormal returns from their portfolio holdings. The second paper is the one by Jeng et al. (2003). They, on the other hand, estimate a proxy for average monthly abnormal returns to insiders from their transactions by employing performance evaluation methods to value weighted purchase and sale portfolios constructed from insider transactions. They identify the holding period of insiders as six months with the help of the short-swing rule of the Security Exchange Act in the United States, which obligates insiders to repay any profit that they earn from their consecutive purchase and sale transactions in their company shares within six months to the company itself. Their results show statistically significant abnormal returns for the purchase portfolio over the 6-month holding period. This provides evidence against the strong form market efficiency. However, returns to sell portfolio are not statistically significantly different from zero over the 6-month holding period.

There are not many studies analyzing profitability of insider trading in emerging markets. Existing studies include Chiang et al. (2004) on the Taiwan Stock market and Wisniewski and Bohl (2005) on the Polish stock market. Chiang et al. (2004), using similar methodology to Eckbo and Smith (1998), find that insiders of the Taiwan Stock Exchange do not earn above market risk adjusted returns from their holdings. However, Wisniewski and Bohl (2005), using event study methodology, show that insiders of the Warsaw Stock Exchange earn abnormal returns from their transactions and outsiders can also earn abnormal returns by imitating insider transactions on the announcement date. To the best of our knowledge, studies done by Doğu (2007) and Kurtay (2007) are the only studies that analyze existence and persistence of abnormal returns following disclosure of insider transactions for the ISE securities. Doğu (2007), using standard event study methodology, concludes that cumulative abnormal returns following the announcement of the sales of insiders are much higher and do persist over longer horizons compared to cumulative abnormal returns following the announcement of insider purchases. Based on a similar methodology, the findings by Kurtay (2007) confirm the existence of higher abnormal returns for insider sales compared to insider purchases for the days following the announcement of insider trades. However, the results of both of these studies are confounded by overlapping event and/or estimation periods. By using a methodology that is not biased because of overlapping event and/or estimation periods and that accounts for the cross-sectional dependence of abnormal returns on purchase and sale transactions, we hope to provide clearer evidence for the profitability of insider trades both for insiders and outsiders mimicking their trades. 


\section{THE REGULATORY ENVIRONMENT AND THE DATA}

The Capital Markets Board (CMB) of Turkey has regulated insider trading and manipulation since 1992 in Turkey. Standard and legal framework for identifying insiders and requirements on public announcement of their trades are defined by the decrees of the CMB.

Serial: VIII, No: 39 was the decree in effect throughout the sample period of this study, from January 2007 to December 2008. According to the decree of the CMB in Serial: VIII, No: 39, the board of directors, executive officers, or other key employees who hold important administrative or operational positions in the company, individuals or corporations directly or indirectly holding more than $5 \%$ of any equity class and individuals or corporations who act together with them are considered as insiders. Therefore, these groups of investors are legally obligated to inform the ISE of their trades until 9:00 am of the workday following their transaction.

The CMB issued a new decree [Serial: VIII, No: 54] on February 6, 2009. This decree relaxes insiders' obligation to announce their trades immediately to the public. According to this new decree, insiders have to declare their trades to the ISE by no later than 9:00 am of the third workday following their trades. Furthermore, shareholders who do not participate in administrative or operational decision making processes of the company are required to publicly announce their transactions only if these transactions cause them to exceed certain ownership thresholds $(5 \%, 10 \%, 15 \%$, etc.) specified by the decree. Moreover, members of the board of directors, executive officers, and other key employees who hold important administrative or operational positions in the company are not required to publicly announce their transactions until the total value of their transactions (direct or indirect) exceeds 10,000 TL within a 12-month time period.

Obviously, prior to February 2009, insiders were required to announce their transactions to the public on a timelier basis. Furthermore, public announcement of all trades was required regardless of the effect of that trade on the ownership share of the insider. For these reasons, the insider-trading sample of this study ends in December 2008 in order to avoid working with a dataset collected from two different regulatory environments.

According to the decree of CMB in Serial: VIII, No: 39, the announcement forms of insider trading ${ }^{(4)}$ sent to the ISE should contain the following information: name of the reporter, issuer name or ticker symbol, transaction date, type of transaction (buy or sell), relationship of the reporter to the issuer, number of shares traded, per share price of equities traded, total value of the transaction, nominal value of shares owned after the transaction and the proportion of the total shares of the company owned by the reporter after the transaction. For the period of the analysis, attachments to company news and daily bulletins are investigated for insider transactions, and the dataset needed for empirical analysis is created manually by collecting information reported for each observation. ${ }^{(5)}$

Following the creation of this dataset, duplicate entries, unreadable, and inaccurate records are eliminated. In addition, transactions of insiders of companies that have more than one type of shares traded on the ISE are eliminated from the dataset. ${ }^{(6)}$ Observations that do not contain the following information are eliminated from the dataset: the type of the transaction, number of shares traded, transaction price and transaction date. Observations stating the transaction date as a time interval, and insider trades which occurred before the analysis period, but announced to public during the analysis period are also eliminated from the dataset. Observations stating that the transaction occurred off-the- 
market or between family members are excluded from the dataset, since these types of transactions are generally executed for corporate control benefits, or diversification or liquidity needs of insiders at negotiated prices instead of market prices.

In addition, price and volume filters are utilized to identify possibly miscoded reports or off-the-market transactions. Volume filter identifies transactions that involve the number of shares that is more than the total number of shares of that security traded in the market on the transaction day. Price filter identifies transactions whose price falls outside the daily trading range of the security. Obviously, these filters cannot possibly catch all off-the-market transactions and miscoded disclosures but they help in reducing the bias that could be introduced into our result from large, possibly off-the-market, transactions, miscoded prices and/or miscoded transaction dates. Then, purchases and/or sales by the same insider on the same transaction and announcement day are aggregated into a single observation. The final dataset contains 9,163 insider transactions in shares of 216 companies among 329 companies traded on the ISE during the analysis period of this study.

Table 1 presents the average number of observations and the average days between two observations by dividing all the companies listed on the ISE into 5 groups. For an average company, the expected number of insider transactions is 42.42 during the period from January 1, 2007 to December 31, 2008. Thus, the average time between two insider transactions is 11.83 days assuming that the events are uniformly distributed. As can be seen in Table 1, 36.45\% of the insider transactions take place in 20 companies with the most active insider trading (first tier firms). Furthermore, observations in 40 companies with the most active insider trading (first and second tier firms) account for more than half of the observations. Moreover, an insider trading is expected to be followed by another insider trading, on average, within 3 days for the first tier and within 6 days for the second tier firms. Thus, analyzing insider transactions without taking into account cross-sectional dependence of abnormal returns to these transactions might induce biases to the results.

Table 1

\section{Frequency of Insider Transactions}

\begin{tabular}{lccccc}
\hline $\begin{array}{l}\text { Groups Based } \\
\text { on Number of } \\
\text { Observations }\end{array}$ & $\begin{array}{c}\text { Number of } \\
\text { Companies }\end{array}$ & $\begin{array}{c}\text { Number of } \\
\text { Observations }\end{array}$ & $\begin{array}{c}\text { Observations } \\
(\%)\end{array}$ & $\begin{array}{c}\text { Average } \\
\text { Number of } \\
\text { Observations }\end{array}$ & $\begin{array}{c}\text { Average Time } \\
\text { between two } \\
\text { Observations } \\
\text { (day) }\end{array}$ \\
\hline First Group (1-20) & 20 & 3340 & 36.45 & 167.00 & 3.01 \\
Second Group (21-40) & 20 & 1749 & 19.09 & 87.45 & 5.74 \\
Third Group (41-60) & 20 & 1174 & 12.81 & 58.70 & 8.55 \\
Fourth Group (61-80) & 20 & 937 & 10.23 & 46.85 & 10.72 \\
Others (81-216) & 136 & 1963 & 21.42 & 14.43 & 34.78 \\
Total & 216 & 9163 & 100.00 & 42.42 & 11.83 \\
\hline
\end{tabular}

This table tabulates number of observations, average number of observations per company and average time between observations by segregating traded companies into 5 groups. First group contains most actively traded 20 companies, second group contains next most actively traded 20 companies, and so forth. The last group constitutes of the least actively traded 136 companies. Last row contains all observations within period of analysis. Average number of observations are calculated as the ratio of the number of observations to the number of companies within that group. Average time between observations is calculated by dividing the number of trade days (502 days) in the analysis period with the average number of observations per company for that group. 
Figure 1 presents the monthly TL value of insider net purchases for each month and the ISE-ALL Return Index during the period of the study. Monthly insider net purchase is the difference between insider buying and selling within that month. During the sample period of the study, insiders as a group seem to become net sellers of their company shares only in 6 of the 24 months. As can be seen in Figure 1, the months in which insiders are the net sellers of their company shares, in general, coincide with the peak levels of the ISE-ALL index. Moreover, the net purchases seem to increase during the month following a significant decrease in the index. Thus, insiders might be timing their purchases as contrarian investors, and buying when other market participants are overweighting recent economy wide bad news. These observations seem to be in line with findings of Lakonishok and Lee (2001) on the US stock exchanges.

\section{Figure 1}

\section{Monthly Insider Net Purchases based on TL Value of the Transactions and the ISE-ALL Return Index during the Period of the Study}

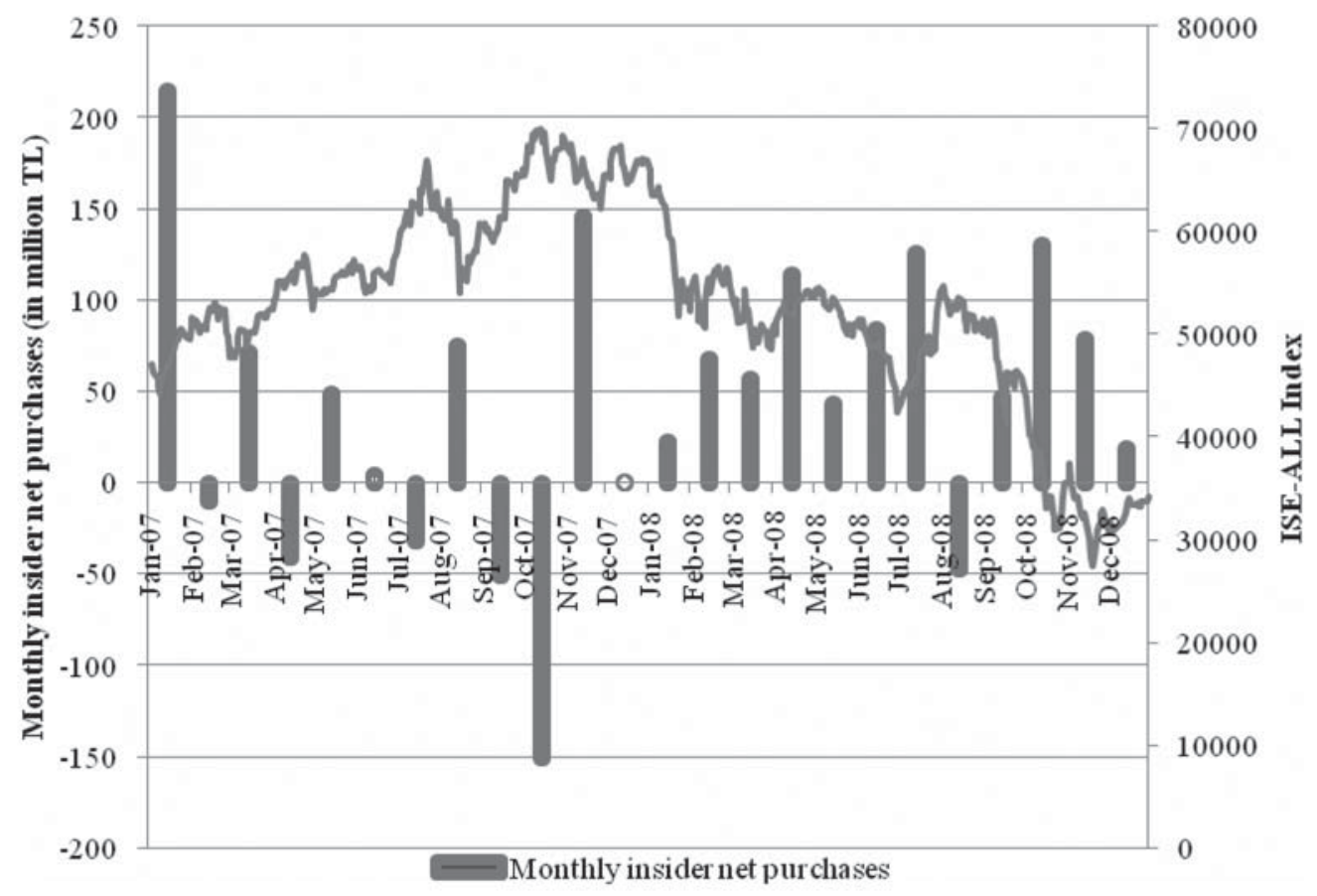

Table 2 summarizes the descriptive statistics related to insider trading data. For the overall dataset, insider purchases outnumber insider sales in terms of the number of observations. However, if the TL value of transactions is considered, the gap between purchases and sales decreases significantly. The mean and median TL values of transactions indicate insiders sell their company shares in substantially larger quantities. In terms of the number of trades, Affiliated shareholders (i.e. Directors, Officers and Affiliated companies) are more frequent traders than Non-Affiliated shareholders. However, Non-Affiliated shareholders are trading in higher TL amounts. In general, Affiliated shareholders seem to be net purchasers of their company shares contrary to the findings of similar studies done on US stock markets. On the other hand, Non-Affiliated shareholders are less intensive buyers compared to Affiliated shareholders during the analysis period. 


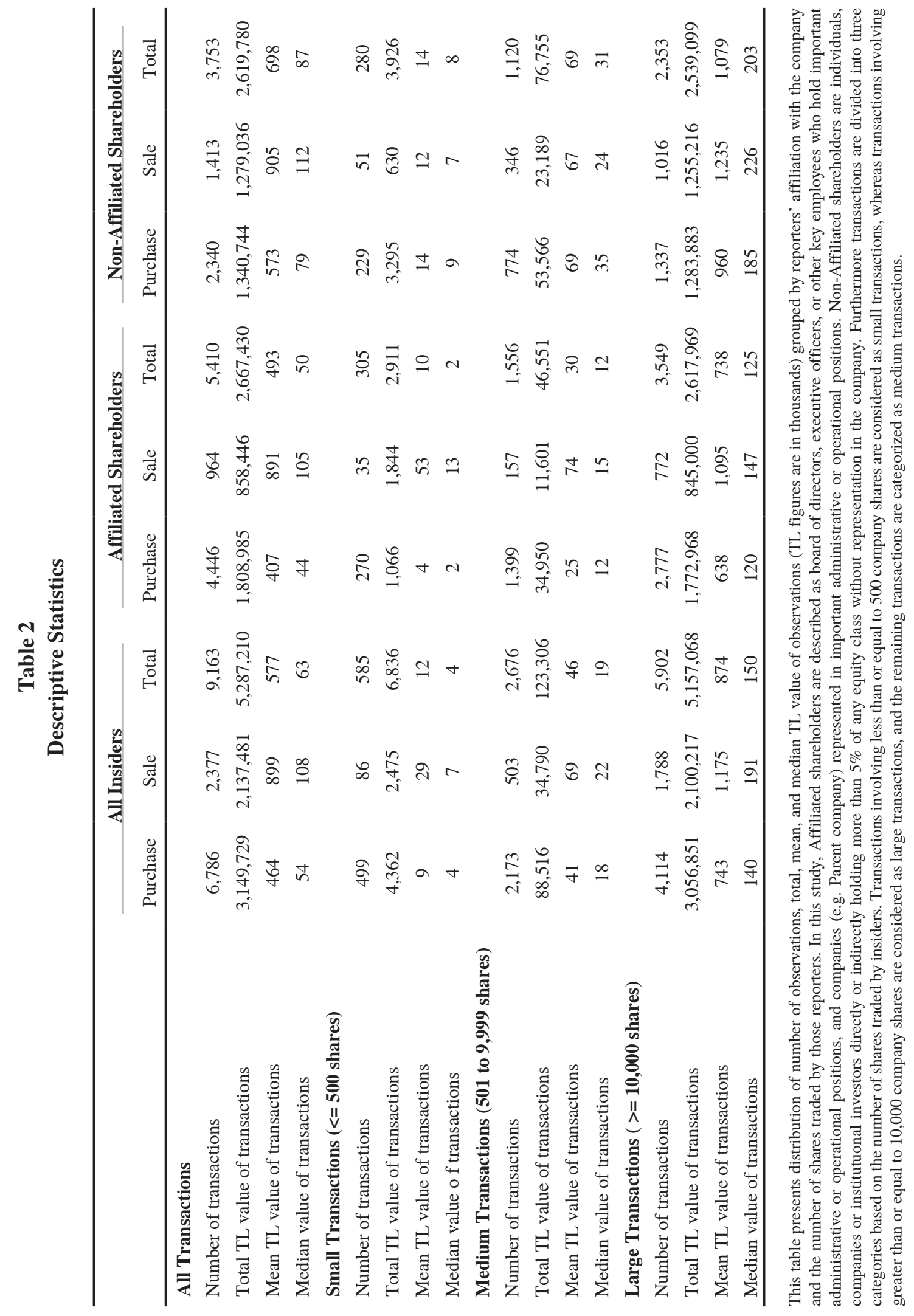


According to Table 2, almost $64.42 \%$ of observations involve daily transactions of insiders in 10,000 or more shares of their companies. Furthermore, these observations constitute $97.54 \%$ of the total TL value traded by insiders. Medium size transactions (between 500 and 9,999 shares) constitute 29.2\% of observations and account only for $2.33 \%$ of total TL value traded. Small transactions seem to be negligible compared to medium and large transactions in terms of the number of observations and underlying TL value, since only about $6.38 \%$ of observations ( $0.13 \%$ of total TL value of observations) come from the trades of insiders in small size. Both Affiliated and Non-Affiliated shareholders seem to be net purchasers regardless of the size of their trades. There is one exception to this conclusion: The Affiliated shareholders seem to be net sellers in small trade sizes.

\section{METHODOLOGY}

The common methodology used in the literature to measure abnormal returns around insider transactions is the event study methodology. The main assumptions of this methodology are that the benchmark model (e.g., the market model, or the capital asset pricing model) captures normal returns, the abnormal returns are concentrated in the event window, and these abnormal returns are normally, independently and identically distributed.

According to Brown and Warner (1985), the event study methodology, when using daily data and calculating normal return estimates from the market model, performs well in detecting abnormal returns for short horizons. However, using the event study methodology for longer horizon studies can have serious problems due to severe departures from the assumptions of the methodology. Major departures from the assumptions are caused by a non-normal return distribution of thinly traded stocks, a bad-model, cross-correlations arising from calendar and/or industry clustering, and autocorrelations in returns due to overlapping event windows for the same firm. ${ }^{(7)}$

Overlapping event periods for the same firm, as stated by Barber et al. (1999) "is the most severe form of cross-sectional dependence that a researcher could encounter in an event study of long-run abnormal stock returns." Obviously, the probability of having an overlapping event window increases as the event period becomes longer. Furthermore, the general approach used in the literature for estimating the expected return of an event stock, i.e., estimating it over a predefined period before the event (e.g. [t-250, t-15], where $t$ is the event date) might lead to over or under estimating abnormal returns if the insiders actively trade the event stock during this estimation period as well. Barber et al. (1999) propose, by citing previous works of Loughran and Ritter (1995), and Spiess and AffleckGraves (1999), the elimination of overlapping observations by pre-event screening. Even though the possibility and implications of overlapping event and estimation periods are generally ignored in the insider trading literature, there are several studies, such as Del Brio et al. (2002), Tourani-Rad and Gilbert (2004) and Klinge et al. (2005), which take care of overlapping event and estimation periods by eliminating overlapping insider transactions. However, eliminating observations has a drawback of testing smaller samples consisting of firms in which insiders are less active.

The methodology proposed in this study is to estimate the return performance of insiders by simultaneously working two rolling portfolios, namely Net Purchase Portfolio (NP portfolio) and Net Sale Portfolio (NS portfolio), constructed from the daily insider trading data. This methodology is selected in order to account for the dependence of returns to purchases and sales of insiders of the same firm. The portfolio formation methods used in this study differ from the one used in Jeng 
et al. (2003) in three ways. First, purchase and sale transactions of insiders are allocated to the net purchase and net sale portfolio to reflect the net positions of insiders as a group in underlying company shares at all points in time. Second, rather than forcing insiders to reverse their positions in a single predefined holding period (e.g. 6 months), the position reversals of insiders within a holding period are executed in the portfolios. Last, due to lack of regulations restricting insiders to exploit short-term profit opportunities at any time, throughout this study, these portfolios are constructed over various predefined holding periods ${ }^{(8)}$ (5-, 10-, 21-, 42- and 63-day holding periods). The longest predefined holding period is selected as 63 trading days (approximately 3 months) based on the results of an analysis not reported here. It is calculated from the insider trading dataset that, on average, an insider sells (repurchases) some portion of stocks s/he purchased (sold) 63.93 (52.47) days after the original trade.

In order to construct NP and NS portfolios, it is assumed that each insider holds her/his initial trade position, at most, to the end of a predefined holding period. Therefore, insiders are forced to reverse their initial positions T-days after the opening of these positions. If an insider reverses some portion of her/his transaction prior to the end of this predefined holding period, s/he is forced to reverse only the remaining amount at the end of the predefined holding period interval. Moreover, the first in first out (FIFO) principle is used to estimate changes in the net position of each insider in the underlying company shares. To exemplify, if insider A buys $2 X$ shares on day $t$, buys $X$ shares on day $t+2$, and sells $\mathrm{X}$ shares on day $\mathrm{t}+4$, the procedure explained above forces the insider to sell $\mathrm{X}$ amount at time $\mathrm{t}+\mathrm{T}$ and $\mathrm{X}$ amount at time $(\mathrm{t}+2)+\mathrm{T}$. These reversals are treated as hypothetical trade reports sent to the ISE on the day of the forced reversal.

The formation heuristics for these portfolios can be summarized as follows. At any given day t, when an insider purchases X shares of company A, NP portfolio checks the position of NS portfolio related to the underlying stock. If portfolio NS does not hold any position in the stocks of company A, then portfolio NP purchases X amount of company A shares at the closing price on the day insider transaction occurs. Suppose NS portfolio holds Y shares (which means insiders as a group are net sellers over the previous $T$ days) in company A. If $Y \geq X$, NS portfolio sells $X$ shares and NP portfolio simply discards the buy signal. If $\mathrm{Y}<\mathrm{X}$, NS portfolio sells $\mathrm{Y}$ shares of company A, and NP portfolio purchases $(\mathrm{X}-\mathrm{Y})$ shares of the company $\mathrm{A}$ at its closing price on the day of transaction. This approach is similar for sale transactions.

On each day, the resulting net purchase (net sale) portfolio would hold long positions in shares of the companies in which insiders, as a group, are net purchasers (net sellers) over the previous T days, considering the position reversals of insiders within the holding period. As a result, if insiders earn positive abnormal returns on their net purchases, the return on the NP portfolio is expected to be positive as well. On the other hand, if insiders earn positive abnormal returns on their net sales, the return on the NS portfolio is expected to be negative since the NS portfolio has long positions in these shares. NP and NS portfolios are essentially similar to daily value weighted calendar-time portfolios, since, each day, their compositions would change based on the transactions of insiders. ${ }^{(9)}$ Therefore, the daily returns to NP and NS portfolios are calculated by taking the value weighted average of returns to stocks in those portfolios based on the TL value of these stocks on the previous day.

$$
\mathrm{R}_{\mathrm{i}, \mathrm{t}}=\sum_{j=1}^{j=N}\left(w_{j, t-1} \cdot R_{j, t}\right)
$$


where $i$ is the Net Purchase or Net Sale portfolio, $R_{i, t}$ is the value weighted return on portfolio $i$ on day $t, N$ is the number of securities in portfolio $i$ on day $t-1, w_{j, t-1}$ is the proportion of stock $\mathrm{j}$ in portfolio $\mathrm{i}$ based on TL value on day $\mathrm{t}-1$, and $\mathrm{R}_{\mathrm{j}, \mathrm{t}}$ is the dividend and split adjusted return of stock $\mathrm{j}$ on day $\mathrm{t}$.

In addition, the first 63 days, based on the longest predefined holding period, are selected as portfolio build-up period and eliminated from the daily return series of NP and NS portfolios to avoid analyzing portfolios containing shares of very few companies. Furthermore, this portfolio build-up period helps to achieve comparable results for portfolios with different predefined holding periods.

In this section, portfolio formation procedures are explained for the insider portfolios. Procedures for the outsider portfolios are essentially the same with one exception. Outsider portfolios are constructed to replicate insider transactions at the closing prices on the day following the announcement day of these trades in the Daily Bulletins posted on the ISE's website. ${ }^{(10)}$

The risk-adjusted return performance of portfolios is measured using the Three Factor Model, proposed by Fama and French (1993). The size and the Book to Market (B/M) ratio return indices are constructed following the procedure explained in Fama and French (1993) using daily returns instead of monthly returns: ${ }^{(11)}$

$$
\mathrm{R}_{\mathrm{i}, \mathrm{t}}-\mathrm{R}_{\mathrm{f}, \mathrm{t}}=\alpha_{\mathrm{i}}+\beta_{\mathrm{i}, 1} \cdot\left(\mathrm{R}_{\mathrm{M}, \mathrm{t}}-\mathrm{R}_{\mathrm{f}, \mathrm{t}}\right)+\beta_{\mathrm{i}, 2} \cdot \mathrm{SMB}_{\mathrm{t}}+\beta_{\mathrm{i}, 3} \cdot \mathrm{HML}_{\mathrm{t}}+\varepsilon_{\mathrm{i}, \mathrm{t}}
$$

where $i$ is the Net Purchase or Net Sale portfolio, $R_{i, t}$ is the value weighted return on portfolio $i, R_{f, t}$ is the risk free rate proxied by the daily repo rate, and $\mathrm{R}_{\mathrm{M}, \mathrm{t}}$ is the value weighted daily return on the market portfolio proxied by the ISE-ALL return index, $\mathrm{SMB}_{\mathrm{t}}$ is the size index, and $\mathrm{HML}_{\mathrm{t}}$ is the $\mathrm{B} / \mathrm{M}$ ratio index on day t. Here $\alpha_{i}$ can be interpreted as the daily average abnormal return to portfolio i.

If the market is efficient and the three Fama and French factors capture all the relevant risks in estimating normal returns to a portfolio, and insiders are not trading based on material non-public information, then it is expected that, for each of the portfolios constructed, $\alpha_{i}$ should not be statistically significantly different from zero. The following hypothesis is tested for the portfolios and subportfolios constructed in the empirical results section:

$$
\begin{aligned}
& H_{0,1}: \text { Daily average abnormal return to portfolio i is equal to zero }\left(\alpha_{i}=0\right) . \\
& H_{a, 1} \text { : Daily average abnormal return to portfolio i is not equal to zero }\left(\alpha_{i} \neq 0\right) .
\end{aligned}
$$

\section{EMPIRICAL RESULTS}

\section{Results for Overall Portfolios}

In this subsection, empirical results for the insider and outsider portfolios that are constructed by using all insider trading records reported to the ISE are discussed. Results reported in Panel A of Table 3, show that a net purchase portfolio earns a statistically significant ${ }^{(12)}$ positive daily Average Abnormal return (AAR) only over a 5-day holding period. On the other hand, outsiders cannot earn positive AARs by purchasing stocks that are net purchased by insiders (Table 3, Panel A) over any holding periods. 
When risk adjusted return performances of net insider sale portfolios are investigated, results shown in Panel B of Table 3 indicate that there exists a statistically significant negative daily AAR over a 5-day holding period. However, abnormal returns to outsider net sale portfolios are not statistically significantly different from zero over any of the holding periods analyzed in this paper (Panel B of Table 3).

Table 3

Risk Adjusted Returns to Portfolios Constructed from All Insider Transactions

Panel A: Net Purchase Portfolios

\begin{tabular}{|c|c|c|c|c|c|c|c|c|c|c|}
\hline \multirow[b]{2}{*}{$\begin{array}{l}\text { Holding } \\
\text { Period }\end{array}$} & \multicolumn{5}{|c|}{ Insider } & \multicolumn{5}{|c|}{ Outsider } \\
\hline & 5-day & 10-day & 21-day & 42-day & 63-day & 5-day & 10-day & 21-day & 42-day & 63-day \\
\hline$\alpha$ & $\begin{array}{l}0.139 \% \\
(0.021)\end{array}$ & $\begin{array}{l}0.059 \% \\
(0.265)\end{array}$ & $\begin{array}{l}0.027 \% \\
(0.578)\end{array}$ & $\begin{array}{c}-0.019 \% \\
(0.676)\end{array}$ & $\begin{array}{c}-0.059 \% \\
(0.166)\end{array}$ & $\begin{array}{l}0.062 \% \\
(0.294)\end{array}$ & $\begin{array}{l}0.029 \% \\
(0.580)\end{array}$ & $\begin{array}{c}-0.010 \% \\
(0.833)\end{array}$ & $\begin{array}{c}-0.032 \% \\
(0.499)\end{array}$ & $\begin{array}{c}-0.073 \% \\
(0.084)\end{array}$ \\
\hline$\beta_{\mathrm{RM}-\mathrm{RF}}$ & $\begin{array}{c}0.878 \\
(0.000)\end{array}$ & $\begin{array}{c}0.830 \\
(0.000)\end{array}$ & $\begin{array}{c}0.827 \\
(0.000)\end{array}$ & $\begin{array}{c}0.826 \\
(0.000)\end{array}$ & $\begin{array}{c}0.831 \\
(0.000)\end{array}$ & $\begin{array}{c}0.854 \\
(0.000)\end{array}$ & $\begin{array}{c}0.815 \\
(0.000)\end{array}$ & $\begin{array}{c}0.831 \\
(0.000)\end{array}$ & $\begin{array}{c}0.815 \\
(0.000)\end{array}$ & $\begin{array}{c}0.835 \\
(0.000)\end{array}$ \\
\hline$\beta_{\mathrm{SMB}}$ & $\begin{array}{c}0.441 \\
(0.000)\end{array}$ & $\begin{array}{c}0.403 \\
(0.000)\end{array}$ & $\begin{array}{c}0.339 \\
(0.000)\end{array}$ & $\begin{array}{c}0.372 \\
(0.000)\end{array}$ & $\begin{array}{c}0.377 \\
(0.000)\end{array}$ & $\begin{array}{c}0.378 \\
(0.000)\end{array}$ & $\begin{array}{c}0.347 \\
(0.000)\end{array}$ & $\begin{array}{c}0.350 \\
(0.000)\end{array}$ & $\begin{array}{c}0.352 \\
(0.000)\end{array}$ & $\begin{array}{c}0.393 \\
(0.000)\end{array}$ \\
\hline$\beta_{\mathrm{HML}}$ & $\begin{array}{c}0.195 \\
(0.024)\end{array}$ & $\begin{array}{c}0.175 \\
(0.022)\end{array}$ & $\begin{array}{c}0.180 \\
(0.010)\end{array}$ & $\begin{array}{c}0.205 \\
(0.002)\end{array}$ & $\begin{array}{c}0.184 \\
(0.003)\end{array}$ & $\begin{array}{c}0.158 \\
(0.062)\end{array}$ & $\begin{array}{c}0.170 \\
(0.024)\end{array}$ & $\begin{array}{c}0.168 \\
(0.016)\end{array}$ & $\begin{array}{c}0.183 \\
(0.007)\end{array}$ & $\begin{array}{c}0.161 \\
(0.008)\end{array}$ \\
\hline Adj. $R^{2}$ & 0.685 & 0.714 & 0.752 & 0.768 & 0.799 & 0.683 & 0.716 & 0.754 & 0.758 & 0.803 \\
\hline F statistic & 0.000 & 0.000 & 0.000 & 0.000 & 0.000 & 0.000 & 0.000 & 0.000 & 0.000 & 0.000 \\
\hline
\end{tabular}

Panel B: Net Sale Portfolios

\begin{tabular}{|c|c|c|c|c|c|c|c|c|c|c|}
\hline \multirow[b]{2}{*}{$\begin{array}{l}\text { Holding } \\
\text { Period }\end{array}$} & \multicolumn{5}{|c|}{ Insider } & \multicolumn{5}{|c|}{ Outsider } \\
\hline & 5-day & 10-day & 21-day & 42-day & 63-day & 5-day & 10-day & 21-day & 42-day & 63-day \\
\hline$\alpha$ & $\begin{array}{c}-0.320 \% \\
(0.001)\end{array}$ & $\begin{array}{c}-0.161 \% \\
(0.073)\end{array}$ & $\begin{array}{c}-0.152 \% \\
(0.037)\end{array}$ & $\begin{array}{c}-0.028 \% \\
(0.649)\end{array}$ & $\begin{array}{c}-0.038 \% \\
(0.597)\end{array}$ & $\begin{array}{c}-0.150 \% \\
(0.144)\end{array}$ & $\begin{array}{c}-0.173 \% \\
(0.048)\end{array}$ & $\begin{array}{c}-0.087 \% \\
(0.230)\end{array}$ & $\begin{array}{c}-0.038 \% \\
(0.577)\end{array}$ & $\begin{array}{c}-0.014 \% \\
(0.849)\end{array}$ \\
\hline$\beta_{\mathrm{RM}-\mathrm{RF}}$ & $\begin{array}{c}0.979 \\
(0.000)\end{array}$ & $\begin{array}{c}0.928 \\
(0.000)\end{array}$ & $\begin{array}{c}1.010 \\
(0.000)\end{array}$ & $\begin{array}{c}0.869 \\
(0.000)\end{array}$ & $\begin{array}{c}0.931 \\
(0.000)\end{array}$ & $\begin{array}{c}0.975 \\
(0.000)\end{array}$ & $\begin{array}{c}0.967 \\
(0.000)\end{array}$ & $\begin{array}{c}1.016 \\
(0.000)\end{array}$ & $\begin{array}{c}0.881 \\
(0.000)\end{array}$ & $\begin{array}{c}0.919 \\
(0.000)\end{array}$ \\
\hline$\beta_{\mathrm{SMB}}$ & $\begin{array}{c}0.372 \\
(0.001)\end{array}$ & $\begin{array}{c}0.295 \\
(0.004)\end{array}$ & $\begin{array}{c}0.524 \\
(0.000)\end{array}$ & $\begin{array}{c}0.403 \\
(0.000)\end{array}$ & $\begin{array}{c}0.458 \\
(0.000)\end{array}$ & $\begin{array}{c}0.425 \\
(0.000)\end{array}$ & $\begin{array}{c}0.384 \\
(0.000)\end{array}$ & $\begin{array}{c}0.527 \\
(0.000)\end{array}$ & $\begin{array}{c}0.357 \\
(0.000)\end{array}$ & $\begin{array}{c}0.465 \\
(0.000)\end{array}$ \\
\hline$\beta_{\mathrm{HML}}$ & $\begin{array}{c}0.228 \\
(0.108)\end{array}$ & $\begin{array}{c}0.165 \\
(0.198)\end{array}$ & $\begin{array}{c}0.119 \\
(0.251)\end{array}$ & $\begin{array}{c}0.054 \\
(0.547)\end{array}$ & $\begin{array}{l}-0.030 \\
(0.767)\end{array}$ & $\begin{array}{c}0.141 \\
(0.334)\end{array}$ & $\begin{array}{c}0.127 \\
(0.308)\end{array}$ & $\begin{array}{c}0.046 \\
(0.655)\end{array}$ & $\begin{array}{c}0.010 \\
(0.918)\end{array}$ & $\begin{array}{l}-0.004 \\
(0.970)\end{array}$ \\
\hline Adj. $R^{2}$ & 0.508 & 0.535 & 0.663 & 0.666 & 0.634 & 0.484 & 0.562 & 0.664 & 0.631 & 0.626 \\
\hline F statistic & 0.000 & 0.000 & 0.000 & 0.000 & 0.000 & 0.000 & 0.000 & 0.000 & 0.000 & 0.000 \\
\hline
\end{tabular}

Panel A of this table presents the risk adjusted returns to net purchase portfolios constructed from stocks for which all insiders are net buyers over the previous t days (different holding periods). Panel B presents risk adjusted returns to net sale portfolios constructed from stocks for which all insiders are net sellers over the previous t days (different holding periods). Insider portfolios are constructed using the closing prices of the trading day. Outsider portfolios are constructed by replicating insiders transactions one day after the announcement of these transactions. Risk adjusted returns are calculated by using the Fama-French three-factor model. $\alpha$ is the regression intercept, and the $\beta_{\mathrm{RM}-\mathrm{RF}}$, the $\beta_{\mathrm{SMB}}$ and the $\beta_{\mathrm{HML}}$ are the risk premiums for the market, small minus big and high minus low risk factors. P-values for these coefficient estimates are reported in parentheses. The last two rows report the adjusted R-square and significance of the F-statistic for the regressions.

The analyses conducted in this section indicate that insiders, in general, earn abnormal returns from their transactions over short horizons but uninformed investors cannot earn these returns by merely mimicking reported transactions of all insiders. This finding might indicate that investors perceive reported insider transactions as a signal of firm value and quickly adjust the prices of traded stocks. 
However, analyses done based on aggregate disclosure data would only answer the question of whether persons/corporations who are required to report their transactions to the ISE earn abnormal returns from their transactions and whether these returns are available to other investors replicating reported transactions.

\section{Results Based on the Position of the Insider in the Company}

Several studies (e.g., Baesel and Stein, 1979; Jaffe, 1974; Seyhun, 1986, 1998) show differing profits to insiders based on their affiliation with the company. ${ }^{(13)}$ In order to test whether abnormal returns earned by insiders or outsiders following the trades of insiders differ across Affiliated shareholders (Officers, Directors and Affiliated companies) and Non-Affiliated shareholders (Shareholders and Institutional investors), two subportfolios, one for the Affiliated and another one for the Non-Affiliated shareholders, are constructed. Since Affiliated shareholders are more likely to have access to material nonpublic information as opposed to Non-Affiliated shareholders, we expect to find persistent abnormal returns for the Affiliated shareholders.

Affiliated shareholders. Affiliated shareholders, as a group, experience a statistically significant positive daily average abnormal performance over the 5-day holding period from their net purchases (Panel A of Table 4). According to the daily AARs reported in the last five columns of Panel A of Table 4, outsiders cannot earn above market returns on a risk adjusted basis by merely purchasing stocks that are net bought by Affiliated shareholders. However, the portfolio of stocks in which Affiliated shareholders are net sellers seems to underperform the market on a risk-adjusted basis over all holding periods (Panel B of Table 4). This underperformance is also statistically significant. Since Affiliated shareholders are selling these stocks, they are avoiding these negative abnormal returns. Similarly, outsiders can avoid negative abnormal returns by not purchasing or selling stocks that are net sold by Affiliated shareholders over all holding periods (Panel B of Table 4).

Non-Affiliated shareholders. Insider and outsider portfolios of stocks that are net purchased by NonAffiliated shareholders do not experience statistically significant positive abnormal returns over any holding periods (Panel A of Table 5). On the other hand, according to Panel B of Table 5, the portfolio of stocks that are net sold by Non-Affiliated shareholders statistically significantly underperforms the market on a risk adjusted basis over the 5-day holding period. However, outsiders cannot earn abnormal returns by short selling stocks that are net sold by Non-Affiliated shareholders regardless of the holding period analyzed (Panel B of Table 5).

There are several implications of the results reported in Tables 4 and 5. First, statistically significant negative abnormal returns to net sale portfolios of Affiliated shareholders for all holding periods as opposed to abnormal returns to that of Non-Affiliated shareholders only over the 5-day holding period confirm our expectations regarding the differences between those two groups in having access to material non-public information. Second, abnormal return estimates for net purchase and net sale portfolios of Affiliated shareholders confirm the conclusion drawn by Doğu (2007) and Kurtay (2007). According to Doğu (2007), cumulative abnormal returns to the sales of insiders persist over longer horizons than those to their purchases and thus, insider sales transmit more information than their purchases for the ISE securities. Although, it seems consistent with the findings of an earlier study conducted on the ISE, this finding contradicts with the findings of earlier studies done on the US stock market. ${ }^{(14)}$ There could be several explanations for this puzzle. 
Table 4

Risk Adjusted Returns to Portfolios Constructed from Affiliated Shareholders Transactions

Panel A: Net Purchase Portfolios

\begin{tabular}{|c|c|c|c|c|c|c|c|c|c|c|}
\hline \multirow[b]{2}{*}{$\begin{array}{l}\text { Holding } \\
\text { Period }\end{array}$} & \multicolumn{5}{|c|}{ Insider } & \multicolumn{5}{|c|}{ Outsider } \\
\hline & 5-day & 10-day & 21-day & 42-day & 63-day & 5-day & 10-day & 21-day & 42-day & 63-day \\
\hline$\alpha$ & $\begin{array}{l}0.185 \% \\
(0.005)\end{array}$ & $\begin{array}{l}0.106 \% \\
(0.096)\end{array}$ & $\begin{array}{l}0.048 \% \\
(0.433)\end{array}$ & $\begin{array}{c}-0.071 \% \\
(0.194)\end{array}$ & $\begin{array}{c}-0.111 \% \\
(0.024)\end{array}$ & $\begin{array}{l}0.135 \% \\
(0.050)\end{array}$ & $\begin{array}{l}0.059 \% \\
(0.355)\end{array}$ & $\begin{array}{l}0.009 \% \\
(0.887)\end{array}$ & $\begin{array}{c}-0.085 \% \\
(0.120)\end{array}$ & $\begin{array}{c}-0.126 \% \\
(0.011)\end{array}$ \\
\hline$\beta_{\mathrm{RM}-\mathrm{RF}}$ & $\begin{array}{c}0.842 \\
(0.000)\end{array}$ & $\begin{array}{c}0.825 \\
(0.000)\end{array}$ & $\begin{array}{c}0.810 \\
(0.000)\end{array}$ & $\begin{array}{c}0.824 \\
(0.000)\end{array}$ & $\begin{array}{c}0.847 \\
(0.000)\end{array}$ & $\begin{array}{c}0.824 \\
(0.000)\end{array}$ & $\begin{array}{c}0.778 \\
(0.000)\end{array}$ & $\begin{array}{c}0.808 \\
(0.000)\end{array}$ & $\begin{array}{c}0.823 \\
(0.000)\end{array}$ & $\begin{array}{c}0.864 \\
(0.000)\end{array}$ \\
\hline$\beta_{\mathrm{SMB}}$ & $\begin{array}{c}0.250 \\
(0.001)\end{array}$ & $\begin{array}{c}0.285 \\
(0.000)\end{array}$ & $\begin{array}{c}0.250 \\
(0.000)\end{array}$ & $\begin{array}{c}0.331 \\
(0.000)\end{array}$ & $\begin{array}{c}0.389 \\
(0.000)\end{array}$ & $\begin{array}{c}0.199 \\
(0.011)\end{array}$ & $\begin{array}{c}0.207 \\
(0.005)\end{array}$ & $\begin{array}{c}0.266 \\
(0.000)\end{array}$ & $\begin{array}{c}0.336 \\
(0.000)\end{array}$ & $\begin{array}{c}0.423 \\
(0.000)\end{array}$ \\
\hline$\beta_{\mathrm{HML}}$ & $\begin{array}{c}0.173 \\
(0.067)\end{array}$ & $\begin{array}{c}0.223 \\
(0.015)\end{array}$ & $\begin{array}{c}0.213 \\
(0.015)\end{array}$ & $\begin{array}{c}0.260 \\
(0.001)\end{array}$ & $\begin{array}{c}0.253 \\
(0.000)\end{array}$ & $\begin{array}{c}0.193 \\
(0.050)\end{array}$ & $\begin{array}{c}0.174 \\
(0.058)\end{array}$ & $\begin{array}{c}0.204 \\
(0.019)\end{array}$ & $\begin{array}{c}0.265 \\
(0.001)\end{array}$ & $\begin{array}{c}0.225 \\
(0.001)\end{array}$ \\
\hline Adj. $R^{2}$ & 0.638 & 0.643 & 0.655 & 0.706 & 0.757 & 0.613 & 0.618 & 0.656 & 0.706 & 0.761 \\
\hline F statistic & 0.000 & 0.000 & 0.000 & 0.000 & 0.000 & 0.000 & 0.000 & 0.000 & 0.000 & 0.000 \\
\hline
\end{tabular}

Panel B: Net Sale Portfolios

\begin{tabular}{|c|c|c|c|c|c|c|c|c|c|c|}
\hline \multirow[b]{2}{*}{$\begin{array}{l}\text { Holding } \\
\text { Period }\end{array}$} & \multicolumn{5}{|c|}{ Insider } & \multicolumn{5}{|c|}{ Outsider } \\
\hline & 5-day & 10-day & 21-day & 42-day & 63-day & 5-day & 10-day & 21-day & 42-day & 63-day \\
\hline$\alpha$ & $\begin{array}{c}-0.448 \% \\
(0.001)\end{array}$ & $\begin{array}{c}-0.390 \% \\
(0.000)\end{array}$ & $\begin{array}{c}-0.367 \% \\
(0.000)\end{array}$ & $\begin{array}{c}-0.313 \% \\
(0.000)\end{array}$ & $\begin{array}{c}-0.215 \% \\
(0.014)\end{array}$ & $\begin{array}{c}-0.466 \% \\
(0.001)\end{array}$ & $\begin{array}{c}-0.525 \% \\
(0.000)\end{array}$ & $\begin{array}{c}-0.329 \% \\
(0.001)\end{array}$ & $\begin{array}{c}-0.306 \% \\
(0.000)\end{array}$ & $\begin{array}{c}-0.221 \% \\
(0.011)\end{array}$ \\
\hline$\beta_{\mathrm{RM}-\mathrm{RF}}$ & $\begin{array}{c}0.801 \\
(0.000)\end{array}$ & $\begin{array}{c}0.830 \\
(0.000)\end{array}$ & $\begin{array}{c}0.988 \\
(0.000)\end{array}$ & $\begin{array}{c}0.977 \\
(0.000)\end{array}$ & $\begin{array}{c}0.962 \\
(0.000)\end{array}$ & $\begin{array}{c}0.883 \\
(0.000)\end{array}$ & $\begin{array}{c}0.946 \\
(0.000)\end{array}$ & $\begin{array}{c}1.000 \\
(0.000)\end{array}$ & $\begin{array}{c}0.971 \\
(0.000)\end{array}$ & $\begin{array}{c}0.962 \\
(0.000)\end{array}$ \\
\hline$\beta_{\mathrm{SMB}}$ & $\begin{array}{c}0.290 \\
(0.049)\end{array}$ & $\begin{array}{c}0.258 \\
(0.037)\end{array}$ & $\begin{array}{c}0.586 \\
(0.000)\end{array}$ & $\begin{array}{c}0.544 \\
(0.000)\end{array}$ & $\begin{array}{c}0.471 \\
(0.000)\end{array}$ & $\begin{array}{c}0.524 \\
(0.001)\end{array}$ & $\begin{array}{c}0.490 \\
(0.000)\end{array}$ & $\begin{array}{c}0.633 \\
(0.000)\end{array}$ & $\begin{array}{c}0.567 \\
(0.000)\end{array}$ & $\begin{array}{c}0.483 \\
(0.000)\end{array}$ \\
\hline$\beta_{\text {HML }}$ & $\begin{array}{c}0.046 \\
(0.805)\end{array}$ & $\begin{array}{c}0.056 \\
(0.722)\end{array}$ & $\begin{array}{l}-0.081 \\
(0.556)\end{array}$ & $\begin{array}{l}-0.035 \\
(0.779)\end{array}$ & $\begin{array}{l}-0.090 \\
(0.474)\end{array}$ & $\begin{array}{c}0.209 \\
(0.275)\end{array}$ & $\begin{array}{c}0.108 \\
(0.511)\end{array}$ & $\begin{array}{l}-0.037 \\
(0.783)\end{array}$ & $\begin{array}{l}-0.037 \\
(0.760)\end{array}$ & $\begin{array}{l}-0.096 \\
(0.438)\end{array}$ \\
\hline Adj. $R^{2}$ & 0.283 & 0.381 & 0.514 & 0.552 & 0.551 & 0.295 & 0.405 & 0.524 & 0.570 & 0.556 \\
\hline F statistic & 0.000 & 0.000 & 0.000 & 0.000 & 0.000 & 0.000 & 0.000 & 0.000 & 0.000 & 0.000 \\
\hline
\end{tabular}

Panel A of this table presents the risk adjusted returns to net purchase portfolios constructed from stocks for which Affiliated shareholders are net buyers over the previous t days (different holding periods). Panel B presents risk adjusted returns to net sale portfolios constructed from stocks for which Affiliated shareholders are net sellers over the previous t days (different holding periods). Insider portfolios are constructed using the closing prices of the trading day. Outsider portfolios are constructed by replicating the transactions of Affiliated shareholders one day after the announcement of these transactions. Risk adjusted returns are calculated by using the Fama-French three-factor model. $\alpha$ is the regression intercept, and the $\beta_{\mathrm{RM}-\mathrm{RF}}$, the $\beta_{\mathrm{SMB}}$ and the $\beta_{\mathrm{HML}}$ are the risk premiums for the market, small minus big and high minus low risk factors. P-values for these coefficient estimates are reported in parentheses. The last two rows report the adjusted R-square and significance of the F-statistic for the regressions.

In similar studies done in the US, Affiliated shareholders (mainly officers and members of boards of directors) are net sellers of their companies' stocks. This finding is not surprising since these groups receive stock options and warrants from their companies as a part of their compensation packages. Thus, sale transactions outnumber purchase transactions due to diversification and liquidity needs of these insiders. On the other hand, for the ISE, Affiliated shareholders are the net purchasers of their company shares during the sample period of this study. Therefore, Affiliated shareholders might be selling their company shares when they have negative information about their company shares, rather than satisfying their diversification and liquidity needs. Furthermore, they might be purchasing their company's stocks simply because they need to invest their money and not because they have an informational advantage. 
Table 5

Risk Adjusted Returns to Portfolios Constructed from Non-Affiliated shareholders Transactions

Panel A: Net Purchase Portfolios

\begin{tabular}{|c|c|c|c|c|c|c|c|c|c|c|}
\hline \multirow[b]{2}{*}{$\begin{array}{l}\text { Holding } \\
\text { Period }\end{array}$} & \multicolumn{5}{|c|}{ Insider } & \multicolumn{5}{|c|}{ Outsider } \\
\hline & 5-day & 10-day & 21-day & 42-day & 63-day & 5-day & 10-day & 21-day & 42-day & 63-day \\
\hline$\alpha$ & $\begin{array}{l}0.155 \% \\
(0.106)\end{array}$ & $\begin{array}{l}0.086 \% \\
(0.301)\end{array}$ & $\begin{array}{l}0.034 \% \\
(0.629)\end{array}$ & $\begin{array}{l}0.032 \% \\
(0.620)\end{array}$ & $\begin{array}{c}-0.001 \% \\
(0.991)\end{array}$ & $\begin{array}{l}0.062 \% \\
(0.494)\end{array}$ & $\begin{array}{l}0.033 \% \\
(0.683)\end{array}$ & $\begin{array}{c}-0.046 \% \\
(0.506)\end{array}$ & $\begin{array}{c}-0.012 \% \\
(0.857)\end{array}$ & $\begin{array}{c}-0.021 \% \\
(0.722)\end{array}$ \\
\hline$\beta_{\mathrm{RM}-\mathrm{RF}}$ & $\begin{array}{c}0.830 \\
(0.000)\end{array}$ & $\begin{array}{c}0.769 \\
(0.000)\end{array}$ & $\begin{array}{c}0.766 \\
(0.000)\end{array}$ & $\begin{array}{c}0.728 \\
(0.000)\end{array}$ & $\begin{array}{c}0.739 \\
(0.000)\end{array}$ & $\begin{array}{c}0.768 \\
(0.000)\end{array}$ & $\begin{array}{c}0.764 \\
(0.000)\end{array}$ & $\begin{array}{c}0.747 \\
(0.000)\end{array}$ & $\begin{array}{c}0.713 \\
(0.000)\end{array}$ & $\begin{array}{c}0.734 \\
(0.000)\end{array}$ \\
\hline$\beta_{\mathrm{SMB}}$ & $\begin{array}{c}0.654 \\
(0.000)\end{array}$ & $\begin{array}{c}0.612 \\
(0.000)\end{array}$ & $\begin{array}{c}0.563 \\
(0.000)\end{array}$ & $\begin{array}{c}0.469 \\
(0.000)\end{array}$ & $\begin{array}{c}0.392 \\
(0.000)\end{array}$ & $\begin{array}{c}0.628 \\
(0.000)\end{array}$ & $\begin{array}{c}0.608 \\
(0.000)\end{array}$ & $\begin{array}{c}0.596 \\
(0.000)\end{array}$ & $\begin{array}{c}0.430 \\
(0.000)\end{array}$ & $\begin{array}{c}0.388 \\
(0.000)\end{array}$ \\
\hline$\beta_{\text {HML }}$ & $\begin{array}{l}-0.003 \\
(0.982)\end{array}$ & $\begin{array}{c}0.113 \\
(0.343)\end{array}$ & $\begin{array}{c}0.133 \\
(0.187)\end{array}$ & $\begin{array}{c}0.201 \\
(0.030)\end{array}$ & $\begin{array}{c}0.087 \\
(0.298)\end{array}$ & $\begin{array}{c}0.112 \\
(0.388)\end{array}$ & $\begin{array}{c}0.425 \\
(0.000)\end{array}$ & $\begin{array}{c}0.272 \\
(0.006)\end{array}$ & $\begin{array}{c}0.232 \\
(0.016)\end{array}$ & $\begin{array}{c}0.087 \\
(0.299)\end{array}$ \\
\hline Adj. $\mathrm{R}^{2}$ & 0.418 & 0.450 & 0.535 & 0.560 & 0.617 & 0.409 & 0.467 & 0.531 & 0.531 & 0.612 \\
\hline F statistic & 0.000 & 0.000 & 0.000 & 0.000 & 0.000 & 0.000 & 0.000 & 0.000 & 0.000 & 0.000 \\
\hline
\end{tabular}

Panel B: Net Sale Portfolios

\begin{tabular}{|c|c|c|c|c|c|c|c|c|c|c|}
\hline \multirow[b]{2}{*}{$\begin{array}{l}\text { Holding } \\
\text { Period }\end{array}$} & \multicolumn{5}{|c|}{ Insider } & \multicolumn{5}{|c|}{ Outsider } \\
\hline & 5-day & 10-day & 21-day & 42-day & 63-day & 5-day & 10-day & 21-day & 42-day & 63-day \\
\hline$\alpha$ & $\begin{array}{c}-0.251 \% \\
(0.019)\end{array}$ & $\begin{array}{c}-0.106 \% \\
(0.254)\end{array}$ & $\begin{array}{c}-0.072 \% \\
(0.363)\end{array}$ & $\begin{array}{l}0.006 \% \\
(0.931)\end{array}$ & $\begin{array}{c}-0.027 \% \\
(0.722)\end{array}$ & $\begin{array}{c}-0.156 \% \\
(0.132)\end{array}$ & $\begin{array}{c}-0.099 \% \\
(0.284)\end{array}$ & $\begin{array}{c}-0.030 \% \\
(0.720)\end{array}$ & $\begin{array}{l}0.009 \% \\
(0.905)\end{array}$ & $\begin{array}{l}0.010 \% \\
(0.897)\end{array}$ \\
\hline$\beta_{\mathrm{RM}-\mathrm{RF}}$ & $\begin{array}{c}1.010 \\
(0.000)\end{array}$ & $\begin{array}{c}0.973 \\
(0.000)\end{array}$ & $\begin{array}{c}1.032 \\
(0.000)\end{array}$ & $\begin{array}{c}0.903 \\
(0.000)\end{array}$ & $\begin{array}{c}0.955 \\
(0.000)\end{array}$ & $\begin{array}{c}0.998 \\
(0.000)\end{array}$ & $\begin{array}{c}0.976 \\
(0.000)\end{array}$ & $\begin{array}{c}1.031 \\
(0.000)\end{array}$ & $\begin{array}{c}0.902 \\
(0.000)\end{array}$ & $\begin{array}{c}0.941 \\
(0.000)\end{array}$ \\
\hline$\beta_{\mathrm{SMB}}$ & $\begin{array}{c}0.457 \\
(0.000)\end{array}$ & $\begin{array}{c}0.329 \\
(0.002)\end{array}$ & $\begin{array}{c}0.375 \\
(0.000)\end{array}$ & $\begin{array}{c}0.340 \\
(0.000)\end{array}$ & $\begin{array}{c}0.450 \\
(0.000)\end{array}$ & $\begin{array}{c}0.414 \\
(0.000)\end{array}$ & $\begin{array}{c}0.326 \\
(0.002)\end{array}$ & $\begin{array}{c}0.391 \\
(0.000)\end{array}$ & $\begin{array}{c}0.306 \\
(0.000)\end{array}$ & $\begin{array}{c}0.459 \\
(0.000)\end{array}$ \\
\hline$\beta_{\mathrm{HML}}$ & $\begin{array}{c}0.210 \\
(0.171)\end{array}$ & $\begin{array}{c}0.130 \\
(0.330)\end{array}$ & $\begin{array}{c}0.191 \\
(0.094)\end{array}$ & $\begin{array}{c}0.143 \\
(0.152)\end{array}$ & $\begin{array}{c}0.031 \\
(0.771)\end{array}$ & $\begin{array}{l}-0.032 \\
(0.827)\end{array}$ & $\begin{array}{c}0.111 \\
(0.403)\end{array}$ & $\begin{array}{c}0.154 \\
(0.191)\end{array}$ & $\begin{array}{c}0.104 \\
(0.334)\end{array}$ & $\begin{array}{c}0.066 \\
(0.542)\end{array}$ \\
\hline Adj. $R^{2}$ & 0.479 & 0.537 & 0.640 & 0.638 & 0.627 & 0.489 & 0.541 & 0.622 & 0.604 & 0.611 \\
\hline F statistic & 0.000 & 0.000 & 0.000 & 0.000 & 0.000 & 0.000 & 0.000 & 0.000 & 0.000 & 0.000 \\
\hline
\end{tabular}

Panel A of this table presents the risk adjusted returns to net purchase portfolios constructed from stocks for which Non-Affiliated shareholders are net buyers over the previous $t$ days (different holding periods). Panel B presents risk adjusted returns to net sale portfolios constructed from stocks for which Non-Affiliated shareholders are net sellers over the previous t days (different holding periods). Insider portfolios are constructed using the closing prices of the trading day. Outsider portfolios are constructed by replicating transactions of Non-Affiliated shareholders one day after the announcement of these transactions. Risk adjusted returns are calculated by using the Fama-French three-factor model. $\alpha$ is the regression intercept, and the $\beta_{\mathrm{RM}-\mathrm{RF}}$, the $\beta_{\mathrm{SMB}}$ and the $\beta_{\mathrm{HML}}$ are the risk premiums for the market, small minus big and high minus low risk factors. P-values for these coefficient estimates are reported in parentheses. The last two rows report the adjusted R-square and significance of the F-statistic for the regressions.

Other market participants' reaction to the disclosure of Affiliated shareholder transactions might be another explanation. Other market participants might be overreacting (underreacting) to Affiliated shareholders' sale (purchase) transactions since Affiliated shareholders are generally net purchasers and the frequency of their sales (purchases) are relatively low (high) compared to their purchases (sales). Distinguishing between these two possible explanations for the profitability of sale transactions of Affiliated shareholders is beyond the scope of this paper. 


\section{CONCLUSION}

In this study, abnormal returns earned by insiders from their transactions disclosed to the public in compliance with the requirements of the $\mathrm{CMB}$ of Turkey are examined. Our results suggest that Affiliated shareholders can earn above market returns from their transactions on a risk adjusted basis. These returns generally stem from sales rather than purchases, contrary to the findings of similar studies done on the US stock markets. Furthermore, uninformed investors can implement profitable trading strategies by mimicking sale transactions of Affiliated shareholders. These results can be taken as evidence against the semi-strong or the strong form efficiency of the Istanbul Stock Exchange.

Our results indicate market inefficiencies but their sources remain unresolved. Abnormal returns found for net sales might be due to exploitation of material non-public information by Affiliated shareholders (e.g. trading prior to low earnings announcement) or overreaction of other market participants to sales of Affiliated shareholders because of their low frequency. Future research examining trading patterns of Affiliated shareholders and abnormal returns to Affiliated shareholder transactions around corporate news announcements might help in identifying the source of these observed inefficiencies. ${ }^{(15)}$

Several limitations exist in this study. First, although the risk adjusted returns are estimated by constructing value weighted portfolios, equally weighting of each period might still underestimate daily average abnormal return estimates if the trading activities of insiders clustered in time to exploit economy wide misvaluations as stated by Loughran and Ritter (2000). Furthermore, daily changing portfolio sizes might cause heteroscedasticity. These problems can be alleviated by estimating daily average abnormal returns using weighted least squares regression where weighting factors can be based on the daily market value of the portfolios. However, as stated by Mitchell and Stafford (2000), this approach would degrade the benefits of portfolio approach that takes into account cross-correlations among returns to the event firms. Furthermore, neglecting transaction costs might cause overestimation of the risk adjusted returns reported in this study, especially for the portfolios with shorter holding periods. Nonetheless, statistically significant abnormal returns reported for the longer holding periods for the Affiliated shareholders are most likely to persist after adjusting for the transaction costs due to lower portfolio turnover. Last, abnormal return estimates for the insider portfolios might understate actual returns to insiders since these portfolios are constructed using the closing price on the day the transaction occurred instead of the actual prices at which insiders conducted those trades.

\section{NOTES}

1. See e.g., Mitchell and Stafford (2000) for details of calendar time portfolio approach and Campbell et al. (1997) for details of the standard event study methodology.

2. We refer to persons or companies liable for announcing their transactions to the public in accordance with the decrees of the Capital Markets Board of Turkey as insiders.

3. According to Bhattacharya and Daouk (2002), in 87 of 103 countries with stock markets insider trading is regulated by law.

4. Prior to 2005, announcement forms of insider trading were published in the Daily Bulletins of company news or as a paper attachment to the Daily Bulletins of the ISE. After January 24, 2005, 
these forms are published daily in the Daily Bulletins section of the ISE's website (http://www. imkb.gov.tr/bultenler.html) under the name "Attachments to Company News." However, these forms are basically scanned versions of insider faxes and cannot be readily used in statistical analysis. From January 1, 2010, reported insider transactions are announced on the public disclosure website (http://www.kap.gov.tr) rather than the Daily Bulletins section of the ISE's website.

5. For the observations which do not contain information on relationship of the reporter to the issuer, company websites, company news bulletins and annual general meeting records are investigated to identify status of the reporters.

6. These companies are "Adana Çimento Sanayii Türk A.Ş.", "Carrefoursa Carrefour Sabanc1 Ticaret Merkezi A.Ş.”, "Türkiye İş Bankası Anonim Şirketi” and "Kardemir Karabük Demir Çelik Sanayi ve Ticaret A.Ş.”.

7. See Cowan and Sergeant (1996), Kothari and Warner (1997, 2007), Barber and Lyon (1997), Fama (1998), and Barber et al. (1999), for problems encountered in long horizon studies.

8. Predefined holding periods are implemented due to practical limitations in identifying actual holding periods of insiders. For example, when an insider reports that s/he sold shares of her/ his company, s/he might be selling some portion of her/his holdings purchased before the insider status was achieved or prior to the analysis period of this study. Therefore, it is impossible to identify the date these shares are acquired by the insider.

9. Similar to Jeng et al. (2003), these portfolios can also be thought as hypothetical mutual funds changing their portfolio composition in reaction to insider transactions.

10. Daily Bulletins become available on the ISE's website after the market closes on that day. Although in some incidents data vendors (i.e. Reuters, Forex etc.) publicly announce insider transactions during the day, Daily Bulletins are the main medium for public dissemination of insider trading information. Thus, the announcement date of an insider's transaction is taken as the publication date of this information in the Daily Bulletins of the ISE.

11. We would like to thank Rüstem Sultanov for providing book values necessary to construct $\mathrm{HML}_{\mathrm{t}}$ zero investment daily return series.

12. Unless otherwise stated, "significant" refers to two tail significance at the $5 \%$ level throughout the study.

13. Seyhun $(1986,1998)$ also finds differing profits to insiders based on the size of their transactions. Furthermore, according to stealth trading hypothesis of Barclay and Warner (1993), informed investors try to hide themselves from regulatory authorities by trading in medium transaction size (500 to 9,999 company shares) and spreading their transactions over time. In order to test whether abnormal returns to insiders differ based on the size of their transactions and whether stealth trading hypothesis holds for the ISE securities, subportfolios are constructed from medium (500 to 9,999 company shares) and large (over 10,000 company shares) size trades of insiders. It 
is found that net sale portfolios constructed from medium size trades of insiders earn abnormal returns over holding periods up to 42 days whereas net sale portfolios constructed from large size trades of insiders do not earn abnormal returns except for the 5-day holding period. This evidence is consistent with the stealth trading hypothesis. However, when transactions of insiders are analyzed simultaneously based on the size of their transaction and the affiliation of the insider with the company, the differing abnormal return estimates for medium and large size trades seem to mainly stem from the affiliation of the insider with the company but not from the trade size. In order to conserve space, these results are not reported here. However, they are available from the authors upon request.

14. See e.g., Seyhun (1986), or Jeng et al. (2003)

15. Studies focusing on insider trading around corporate news announcements generally find an increase in insider trading around these events and take this as evidence supporting the exploitation of non-public information by insiders. Some examples of these corporate news announcements are: annual management earnings forecasts (Penman, 1982), dividend initiations (Kose and Lang, 1991), new equity issues (Karpoff and Lee, 1991), stock repurchase announcements (Lee et al., 1992) and bankruptcies (Seyhun and Bradley, 1997).

\section{REFERENCES}

Baesel, J.B. and Stein, G.R. (1979). "The Value of Information: Inferences from the Profitability of Insider Trading," Journal of Financial and Quantitative Analysis, 14: 553-571.

Bajo, E. and Petracci, B. (2006). "Do what Insiders Do: Abnormal Performances After the Release of Insiders' Relevant Transactions," Studies in Economics and Finance, 23: 94-118.

Barber, B.M. and Lyon, J.D. (1997). "Detecting Long-Run Abnormal Stock Returns: The Empirical Power and Specification of Test Statistics," Journal of Financial Economics, 43: 341-372.

Barber, B.M., Lyon, J.D., and Tsai, C. (1999). "Improved Methods for Tests of Long-Run Abnormal Stock Returns," Journal of Finance, 54: 165-201.

Barclay, M.J. and Warner, J.B. (1993). "Stealth Trading and Volatility: Which Trades Move Prices?" Journal of Financial Economics, 34: 281-306.

Bettis, C., Vickrey, D., and Vickrey, D.W. (1997). "Mimickers of Corporate Insiders Who Make Large-Volume Trades," Financial Analysts Journal, 53: 57-66.

Betzer, A. and Theissen, E. (2009). "Insider Trading and Corporate Governance: The Case of Germany," European Financial Management, 15: 402-429.

Bhattacharya, U. and Daouk H. (2002). “The World Price of Insider Trading," Journal of Finance, 57: 75-108. 
Brown, S.J. and Warner, J.B. (1985). “Using Daily Stock Returns: The Case of Event Studies,” Journal of Financial Economics, 14: 3-31.

Campbell, J., Lo, A., and MacKinlay, A. (1997). The Econometrics of Financial Markets. New Jersey: Princeton University Press.

Chiang, M., Hwang, L., and Wu, Y. (2004). "Insider Trading Performance in the Taiwan Stock Market," International Journal of Business and Economics, 3: 239-256.

Cowan, A. and Sergeant, A. (1996). “Trading Frequency and Event Study Test Specification,” Journal of Banking and Finance, 20: 1731-1757.

Del Brio, E.B., Miguel, A., and Perote, J. (2002). "An Investigation of Insider Trading Profits in the Spanish Stock Market,” Quarterly Review of Economics and Finance, 42: 73-94.

Doğu, M. (2007). İçerden Öğrenenlerin Hisse Senedi İşlemlerinin İstanbul Menkul Kıymetler Borsasında Test Edilmesi, Published Ph. D. Dissertation, Ankara: Hacettepe University.

Eckbo, B.E. and Smith, D.C. (1998). "The Conditional Performance of Insider Trades," Journal of Finance, 53: 467-498.

Fama, E.F. (1970). "Efficient Capital Markets: A Review of Theory and Empirical Work," Journal of Finance. 25: 383-417.

------, (1998). “Market Efficiency, Long-Term Returns, and Behavioral Finance,” Journal of Financial Economics, 49: 283-306.

Fama, E.F. and French, K.R. (1993). "Common Risk Factors in the Returns on Stocks and Bonds," Journal of Financial Economics, 33: 3-56.

Finnerty, J.E. (1976). “Insiders and Market Efficiency,” Journal of Finance, 31: 1141-1148.

Friederich, S., Gregory, A., Matatko, J., and Tonks, I. (2002). "Short-Run Returns around the Trades of Corporate Insiders on The London Stock Exchange," European Financial Management, 8: 7-30.

Jaffe, J. (1974). “Special Information and Insider Trading," Journal of Business, 47: 410-428.

Jeng, L. A., Metrick, A., and Zeckhauser, R. (2003). "Estimating the Returns to Insider Trading: A Performance-Evaluation Perspective," Review of Economics and Statistics, 85: 453-471.

Karpoff, J.M. and Lee, D. (1991). “Insider Trading before New Issue Announcements,” Financial Management, 20: 18-26.

Klinge, M., Seifert, U., and Stehle, R. (2005). “Abnormal Returns in the Vicinity of Insider Transactions: Unbiased Estimates for Germany.” Available [online] at: http://ssrn.com/abstract=677442 
Kose, J. and Lang, L.H.P. (1991). "Insider Trading around Dividend Announcements: Theory and Evidence," Journal of Finance, 46: 1361-1389.

Kothari, S.P. and Warner, J.B. (1997). "Measuring Long-Horizon Security Price Performance," Journal of Financial Economics, 43: 301-339

-----, (2007). “Econometrics of Event Studies," in B.E. Eckbo (ed.), Handbook of Corporate Finance: Empirical Corporate Finance. Amsterdam: North Holland (Elsevier).

Kurtay, S. (2007). Hisse Senetleri İMKB'de İşlem Gören Şirketlerin Büyük Ortak ve Yöneticilerinin Hisse Alım Satım Açıklamaları'nın Hisse Fiyatına Etkisi, Published Ph. D. Dissertation, Ankara: Ankara University.

Lakonishok, J. and Lee, I. (2001). “Are Insiders' Trades Informative?” Review of Financial Studies, 14: $79-112$.

Lee, D.S., Mikkelson, W.H., and Partch, M.M. (1992). "Managers' Trading Around Stock Repurchases," Journal of Finance, 47: 1947-1961.

Lin, Ji-J. and Howe, J.S. (1990). "Insider Trading in the OTC Market," Journal of Finance, 45: 12731284.

Loughran, T. and Ritter, J.R. (1995). “The New Issues Puzzle,” Journal of Finance, 50: 23-51.

----- (2000), “Uniformly Least Powerful Tests of Market Efficiency," Journal of Financial Economics, 55: $361-389$.

Mitchell, M.L. and Stafford, E. (2000). "Managerial Decisions and Long-Term Stock Price Performance," Journal of Business, 73: 287-329.

Penman, S.H. (1982). "Insider Trading and the Dissemination of Firms' Forecast Information," Journal of Business, 55: 479-503.

Pope, P.F., Morris, R.C., and Peel, D.A. (1990). "Insider Trading: Some Evidence on Market Efficiency and Directors' Share Dealings in Great Britain," Journal of Business Finance and Accounting, 17: 359-380.

Rozeff, M.S. and Zaman, M.A. (1988). "Market Efficiency and Insider Trading: New Evidence," Journal of Business, 61: 25-44.

Seyhun, H.N. (1986). "Insiders' Profits, Costs of Trading, and Market Efficiency," Journal of Financial Economics, 16: 189-212.

------, (1998). Investment Intelligence from Insider Trading. Cambridge, MA: MIT Press. 
Seyhun, H.N. and Bradley, M. (1997). “Corporate Bankruptcy and Insider Trading,” Journal of Business, 70: 189-216.

Spiess, D.K. and Affleck-Graves, J. (1999). “The Long-Run Performance of Stock Returns Following Debt Offerings,” Journal of Financial Economics, 54: 45-73.

Tourani-Rad, A. and Aaron, G. (2004). "The Source of Insider Trading Profits: Evidence from New Zealand," Available [online] at: http://mfs.rutgers.edu/MFC/MFC11/mfcindex/files/MFC-069\%20 Tourani-RadGilbert.pdf.

Wisniewski, T.P. and Bohl, M.T. (2002). "The Information Content of Registered Insider Trading Under Lax Law Enforcement," International Review of Law and Economics, 25: 169-185. 